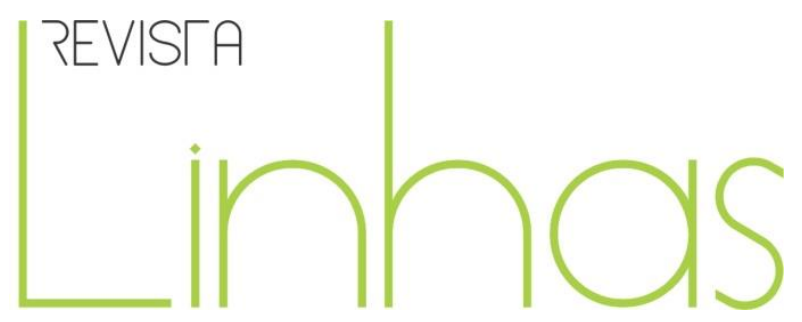

\title{
An Analytical Approach to the Italian Renaissance through Popular TV: The case of Medici
}

\begin{abstract}
This article explores the educational value of using audiovisual media to enhance the learning of history and civilization in foreign language and culture classes. More specifically, it analyzes the pedagogical impact of learning about the Italian Renaissance through a television series about the Medici family, the most acclaimed patrons of the Renaissance. Focusing on the televised adaptation of this family, the article examines how media can revisit and reshape the history of this period through streaming television distribution, the important and highly popular internet-based delivery system of services such as Netflix, Hulu, HBO Go, Amazon Prime Video, YouTube TV, Sling TV, and Fubo TV. I argue that students can become conscious of the mechanisms of historical adaptation by considering their own learned perspectives, and by reshaping them through a highly dramatized and psychologically rooted narrative. Questioning students about the extent to which their understanding of the past is filtered or modified through popular culture-and about the way popular culture uses the past-leads them to think critically about historical continuity. The article pays specific attention to the two main characters in the series, entitled Medici: The Magnificent (2018): the hero, Lorenzo de' Medici, and the villain, Jacopo Pazzi. An accurate historical and cinematic discussion of the two characters will allow me to elucidate the medium-specific potential of the TV series to teach historical facts. Drawing on a few courses I taught on Renaissance Italy, where I implemented this approach, I will demonstrate that students are not just entertained, but also actively engaged in the cognitive aspects barely to be found in written history, namely, the characters' inner lives and struggles. The article will demonstrate that a comparison of the historical sources with their cinematic adaptation is of great pedagogical value for students.
\end{abstract}

Keywords: Italian Renaissance. Popular Culture. History. Adaptation. Pedagogy.

\section{Para citar este artigo:}

MARIANI, Annachiara. An Analytical Approach to the Italian Renaissance through Popular TV: The case of Medici. Revista Linhas. Florianópolis, v. 21, n. 47, p. 194-222, set./dez. 2020. 
Un enfoque

analítico

al

Renacimiento italiano a través de la televisión popular: el caso de Medici

\section{Resumen}

Este artículo explora el valor educativo del uso de medios audiovisuales para mejorar el aprendizaje de la historia y la civilización en las clases de lenguas y culturas extranjeras. Más concretamente, analiza el impacto pedagógico del aprendizaje del Renacimiento italiano a través de una serie de televisión sobre la familia Medici, los mecenas más aclamados del Renacimiento. Centrándose en las adaptaciones televisivas de esta familia, el artículo examina cómo los medios pueden revisar y remodelar la historia de este período a través de la distribución de televisión en línea, el importante y muy popular sistema de entrega de servicios basado en Internet como Netflix, Hulu, HBO Go, Amazon. Prime Video, YouTube TV, Sling TV y Fubo TV. Sostengo que los estudiantes pueden tomar conciencia de los mecanismos de adaptación histórica al considerar sus propias perspectivas aprendidas y al remodelarlas a través de una narrativa altamente dramatizada y psicológicamente arraigada. Cuestionar a los estudiantes sobre la medida en que su comprensión del pasado se filtra o modifica a través de la cultura popular, y sobre la forma en que la cultura popular usa el pasado, los lleva a pensar críticamente sobre la continuidad histórica. El artículo presta especial atención a los dos personajes principales de la serie, titulada Medici: The Magnificent (2018): el héroe, Lorenzo de' Medici, y el villano, Jacopo Pazzi. Una discusión histórica y cinematográfica precisa de los dos personajes me permitirá dilucidar el potencial específico del medio de la serie de televisión para enseñar hechos históricos. Basándome en algunos cursos que impartí sobre la Italia del Renacimiento, donde implementé este enfoque, demostraré que los estudiantes no solo se entretienen, sino que también participan activamente en los aspectos cognitivos que apenas se encuentran en la historia escrita, a saber, la vida interior de los personajes y las luchas internas. El artículo demostrará que una comparación de las fuentes históricas con su adaptación cinematográfica es de gran valor pedagógico para los estudiantes.

Palabras clave: Renacimiento italiano. Cultura popular. Historia. Adaptación. Pedagogía.

\section{Uma abordagem analítica do Renascimento italiano através da televisão popular: o caso dos Medici}

\section{Resumo}

Este artigo explora o valor educacional do uso da mídia audiovisual para realçar o aprendizado da história e da civilização em aulas de língua e cultura estrangeiras. Mais especificamente, analisa o impacto pedagógico de aprender sobre o Renascimento italiano por meio de uma série de televisão sobre a família Médici, os mais aclamados mecenas do Renascimento. Concentrando-se na adaptação desta família para a televisão, o artigo examina como a mídia pode revisitar e remodelar a história desse período por meio da distribuição de transmissão de televisão, o sistema importante e altamente popular de entrega de serviços da Internet, como Netflix, Hulu, HBO Go, Amazon Prime Video, YouTube TV, Sling TV e Fubo TV. Eu demonstro que os alunos podem se tornar conscientes dos mecanismos de adaptação histórica considerando suas próprias perspectivas aprendidas e reformulando-as por meio de uma narrativa altamente dramatizada e psicologicamente enraizada. Questionar os alunos sobre até que ponto sua compreensão do passado é filtrada ou modificada pela cultura popular - e sobre a forma como a cultura popular usa o passado - os leva a pensar criticamente sobre a continuidade histórica. O artigo dá atenção específica aos dois personagens principais da série, intitulada Medici: O Magnífico (2018): o herói, Lorenzo de 'Medici, e o vilão Jacopo Pazzi. Uma discussão histórica e cinematográfica precisa dos dois personagens me permitirá elucidar o potencial médio específico da série de TV para ensinar fatos históricos. Com base em alguns cursos que ministrei na Itália renascentista, onde implementei essa abordagem, demonstrarei que os alunos não apenas se divertem, mas também se envolvem ativamente nos aspectos cognitivos que dificilmente são encontrados na história escrita, ou seja, a vida interior dos personagens e lutas internas. O artigo demonstrará que uma comparação das fontes históricas com sua adaptação cinematográfica é de grande valor pedagógico para os alunos.

Palavras-chave: Renascimento italiano. Cultura popular. História. Adaptação. Pedagogia. 
History is always a mediated experience, but the movement away from text toward virtual or material or physical history presents us with a new and developing historiography. The physical consumption of the historical—economic or otherwise-has been revolutionized. (DE GROOT, 2009, p. 247)

Scholars have dedicated a considerable amount of scholarship on how film and media portray and engage history. Historical film studies is an emerging subfield of history, one dominated mainly by Robert Rosenstone's seminal Visions of the Past (1995). Rosenstone argues rather convincingly that visual media are a viable way of doing history, "of representing, interpreting, thinking about, and making meaning from traces of the past" (1995, p. 3). Consumers of such media understand that they are viewing an adaptation of history, and that they may assume, with some confidence, that the director has a sense of the portrayed history, though they should be ready to accept variances from written historiography. Viewers should also be mindful that the media-adapted version tends to add to established historical facts through aural and visual cues that generate new paths for understanding characters, settings and conflicts. Taking issue with the lingering, dismissive criticism of adaptation, Linda Hutcheon (2012) has recently insisted that the process constitutes a new creation in which "... the act of adaptation always involves both (re-) interpretation and then (re-) creation" (p. 10). In the following pages, I argue that questioning our students about the ways in which their understanding of the past is filtered through popular culture - and about the ways popular culture uses the past - causes them to think critically about established history: what happens in the TV series, what did actually happen, and what is the difference?

Drawing on a few courses I taught on Renaissance Italy, where I implemented this approach, the present article focuses on the pedagogical knowledge-making qualities of the TV series Medici: The Magnificent (2018). Before proceeding with my analysis, I propose a brief overview of the most relevant scholarship on the field of history and audiovisual media and on the pedagogical benefits of teaching history through its screened 
representations. I then trace the evolution of this field of study, setting up my argument on how contemporary audiences and Generation Z students ${ }^{1}$ engage with the audiovisual version of the Medici family. The discussion will demonstrate how this screened adaptation manages to rediscover, divulge, revisit and reshape the historical knowledge of this pivotal period.

\section{Background and framework}

The use of audiovisual technology as a didactic tool has been assessed, among others, by the psychologist Sam Wineburg, in his Historical Thinking and Other Unnatural Acts: Charting the Future of Teaching the Past (2001). Wineburg has worked with young people to determine how they shape their views of the past and found that many of theircorrect or incorrect-ideas came to them through movies and other electronic media. Wineburg concluded from this that their understanding of the world can sometimes be a “crazy patchwork of passively received ideas" (p. 52). Pereboom (2010) asserted that "for an active and a curious mind, film is an extraordinary resource that can, with limitations, transport you through time and space to situations you could otherwise visit only in your dreams or nightmares" (p. 9). Audiovisual technologies enable students to experience the past in a more engaging and appealing way, and to activate imaginations that allow them to reconstruct and understand history. This very reimagination of the past takes form through unique stylistic and narrative devices in film, enabling what Burgoyne (2008) has dubbed as screened "historical reenactments" (pp. 9). Thus, the historical knowledge of the Italian Renaissance as acquired through a TV series stimulates a sort of reenactment, or "affective experiential modes" (LANSDBERG, 2015, p.16) triggered by "prosthetic" memory. Landsberg argues that mass cultural forms such as cinema and television contain

\footnotetext{
${ }^{1}$ According to a research conducted by Vicki Jones, Jun Jo and Philippe Martin, early 21st century students include Millennials and the more recent Generation-Z. Millennials are also known as the Net-Generation or iGeneration, because they were surrounded by digital technologies from a young age. Predictably, Generation- $Z$ will be every bit as technology-savvy as the Millennials. Computers, the Internet, online games and mobile phones are as normal to them as television was to Generation-X. These children have a much higher need for technology-based stimulation than previous generations, leading to a disinterested attitude to traditional methods of education. http://citeseerx.ist.psu.edu/viewdoc/download?doi=10.11.1390.3578\&rep=rep1\&type=pdf.
} 
the still unrealized potential for a progressive politics, based on empathy with the historical experiences of others. The result is a new form of public cultural memory-what Landsberg (2004) calls "prosthetic" memory—that awakens a society's potential for increased social responsibility. Thus, prosthetic memory enables viewers to historically engage in the visual product and affectively experience the past. Landsberg maintains that the ubiquity of this experiential mode conveys an extensive popular desire for a personal connection to the past: "[T] he experiential mode is tactile and material in the bodily sense ... [it] is first and foremost an affective mode: when engaged this way, one's body is touched, moved, provoked" (2004, p.10). In coordination with the aforementioned scholarship, this article aims to explore the extent to which the popular TV series Medici motivates students to engage with events surrounding the Italian Renaissance in a more active way. It does so by demonstrating that students, when they don't passively read textbooks, traditional monographs, or scholarly articles regarding past events, are compelled to actively experience and reflect on it through their own 'reenactments'.

This kind of active engagement with screened history reflects a desire for a personal connection to the past, a process that Rebecca Schneider defines "affective engagement" (2011, p. 8), during which the audience is affectively touched by history. I argue that the experiential or affective mode, in conjunction with more explicitly cognitive modes, can play an important role in the acquisition of historical knowledge. I also aim to show that students can better contextualize Renaissance characters—via audiovisual representation, in the case of Medici-through psychological insight, and what we could call historical psychology. Psychological insight can be understood as people's understanding of their illness, but also as the understanding of "how the illness affects individuals' interactions with the world" (MARKOVÁ and BERRIOS, 1992, p. 850). Historical psychology modifies the idea of psychological insight by extending the viewers' observation by hundreds of years. Thus, modern viewers are able to identify with the dysfunction and turmoil that envelop the lives of the characters. They are also able to understand how the characters interact with the world. This is made possible by the medium-specific nuances of the audiovisual presentation, which include camera angles, lighting, montage, and musical accompaniment. Although a director may choose to manipulate or sensationalize the 
historical content, historical psychology remains a powerful aspect of 'reenactment' that is absent in written history.

This approach is also consistent with the concept of historiophoty, which Hayden White (1988) described in terms of "a representation of history in visual images" (1193). This concept has also been defined as a "magnified miniature of a historical book" (THANOULI, 2019, p.12), because it intensifies and multiplies all the characteristics of written history. Although written texts and screened history can both 'enter' the psyche of historical characters, the anxieties, thrills, fears, and triumphs transmitted by the screen can often convey a higher degree of connectivity. The present article shows that, by shedding light on the hidden subconscious reality of Lorenzo de' Medici and his nemesis Jacopo Pazzi, students acquire a deeper sense of history. Given that there is a lacuna vis-àvis the contribution of the historiophoty, with regard to the history of Italian Renaissance, I hope my contribution will help to fill the existing vacuum.

\section{The Medici case study}

This Italian-British historical series, directed by Frank Spotnitz and Nicholas Meyer between 2016 and 2019, has repopularized interest in the early Italian Renaissance (i.e., the period that mainly covered the fifteenth century). Co-produced by Rai Fiction ${ }^{2}$ and Lux Vide, and internationally distributed by Netflix, the trilogy follows the story of the Florentine family, the Medici. Originally wool merchants, during the Renaissance they became the richest bankers in Europe, and the de facto rulers of the Florentine Republic during the fifteenth and sixteenth centuries. The series' main characters include the family patriarch Giovanni Bicci de’Medici (Season 1), his son Cosimo (Season 1), and Cosimo's grandson Lorenzo (Seasons 2-3). The two co-creators confessed that viewers of their show "don't need to know a thing about Renaissance history to get the most from Medici" (Spotnitz in MELLOR, 2019). During an interview in 2015, Spotnitz made the following statements: "the season will be more thriller than historical saga"; "we begin the show

\footnotetext{
${ }^{2} \mathrm{RAI}$ is the Italian state broadcaster. Rai Fiction is an Italian production company founded in 1997. It is owned and operated by Radiotelevisione Italiana (RAI), the national broadcasting company of Italy.
} 
with a 'what if' because we don't know how Giovanni de' Medici died"; “one of the questions that haunts Cosimo, is whether his father was murdered" (Spotnitz in WAGNER, 2015). Moreover, the co-creators admitted that they wanted to find a way for this story to appeal to people who weren't particularly interested in the Medici, or their place in history; their goal was to create an entertaining story (WAGNER, 2015). They also hoped that viewers empathized with the characters and the family's personal stories, so as to fully participate in the drama of the characters' lives. For instance, Season 1 offers problematic situations such as that which Spotniz describes as follows: "A son who's got to take over from his father, or who is in love with a woman but has to marry somebody else because his family demands it" (MELLOR, 2019). The viewer's emotional participation in the soapopera style series is precisely what allows it to capture a contemporary-and studentaudience, and this is accomplished by offering themes and plotlines linked to universal life struggles. One example might be the theme of absolute patriarchal authority, such as arranged marriages. Although young people in Western societies do not generally face these kinds of restrictions, they are often at odds with their parents' wishes, and in that sense, Medici could appeal to them. When he was about to introduce a scene during a world premiere, Spotnitz in fact noted that Medici has everything, including passion, killing, intrigue, politics, and conspiracy. He concluded by saying that "it's just a wonderful, wonderful story" (Spotnitz in WAGNER, 2015).

Moreover, the different layers of interweaving narratives-typical of the "flexinarrative" (NELSON, 1997)—provide a complex narrative structure that is rich with twists, turns, and surprises, whereas the complexity of characters challenges audiences to keep watching. An example of flexi-narrative structure is the serial delivery of the Medici story, which "better responds to and reveals the complexity, ambiguity and lack of closure that typifies the contemporary world" (CREEBER, 2004, p. 4). Part of the appeal of serialization lies in its ability to construct open-rather than closed-narrative forms, and to borrow from “continuous genres like soap opera” (CREEBER, 2004, p. 4)3. As Creeber puts it,

\footnotetext{
3 Instead of rejecting the claim that much contemporary television drama is 'soap-like', Creeber (2004) argues that this is to the serial drama's benefit. "Soap opera techniques", he writes, "have now become the very means by which radical and progressive drama is frequently conceived and constructed for a contemporary audience" (p. 12). The term 'soap-like'-often used as a criticism, or as a synonym for shallow, formulaic
} 
... the very length and even the 'soapiness' of the serial's form ... makes it an ideal vehicle through which politics and history can be understood; not as mere 'fact' or 'polemic', but as 'memory' and 'experience'.... In particular, the twin characteristics of 'intimacy' and 'continuity' which the historical miniseries shares with soap opera, mean that it can transform history so that it gradually becomes identifiable, empathetic and discursive to a mass audience. (2004, p. 42; italics in original)

The pedagogical value of serialized, historical social dramas becomes apparent: students are seamlessly drawn into the narrative and learn historical facts as effortlessly as they would learn the plot of their favorite TV series. Another element that helps attract audiences is the casting of international celebrities (e.g., Dustin Hoffman, Raul Bova, Sean Bean) and actors already known for their roles in highly popular contemporary series: Richard Madden (Rob Stark in The Game of Thrones), Stuart Martin (a Lannister soldier in The Game of Thrones), Sean Bean (Eddard Stark in The Game of Thrones), Daniel Sherman (Kaleb Westphall in The Originals), Bradley James (Arthur in Merlin), Francesco Montanari (er Libanese in Romanzo Criminale la serie), Toby Regbo (King Frances II of France in Reign), Alessandra Mastronardi (Roberta in Romanzo criminale la serie and Eva Cudicini in I cesaroni), and Matteo Martari (Albert Kroess in Un passo dal cielo). Thus, the Medici series, like other serially delivered historical shows, 'tricks' the audience into learning about the past by disguising its events as star-studded, soap-like episodes that evoke binge-viewing.

The educational and entertaining objectives of this series aptly align with the model of TV programs as advocated by the RAI credo, namely to "inform, educate, entertain, and promote cultural patrimony" (RENGA, 2019, Kindle position 1170), as well as by its slogan: “educate while entertaining - entertain while educating” (ABRUZZESE, 2004, p.146). Barra and Scaglioni (2015) corroborate that the RAl's creed has always been to educate and foster national identity, which is achieved through the production of hagiographies, social dramas, and comedies (p. 67) 4 . As Renga posits, the RAl's educational stance "highlights

\footnotetext{
laziness-is therefore reevaluated, and identified as a politically positive constituent of much contemporary serial drama.

${ }^{4}$ Barra and Scaglioni also advance that "social drama's popularity reflects the incessant need to find a shared story to represent the nation, in the absence of a solid shared past. It is a genre engaged in a piecemeal struggle to construct a national epic" (2015, p. 68).
} 
the informative and appealing nature of Rai programming that is still at the heart of contemporary productions" (2019, Kindle position 1162). Moreover, Lux Vide's productions are centered on the educational imperative in a new context characterized by competition from commercial TV and by the explosion of multichannel offering" (BARRA and SCAGLIONI, 2015, p. 67). In fact, RAl's objective is not unlike the goals of the Public Broadcasting Service (PBS) in the United States (or TV Brasil in Brazil), which began operating in 1970. Competition in the streaming of television services has impelled these models to consider programming that integrates dramatic (and even salacious) plotlines with historical settings, thus casting wider nets to capture greater audiences. There is perhaps no better example of such programming than the wildly popular, socio-historical period drama Downton Abbey (2010-2015) $)^{5}$, which placed fictional narratives in a postEdwardian, British society. Although Downton's Crawley family interacts with international events such as the sinking of the Titanic (1912), the buildup to the Great War (1914), and the Teapot Dome scandal (1921), storylines are invented, making it an attractive intersection between fiction and non-fiction.

We could argue that this is precisely the case of Medici, a socio-historical drama that familiarizes students with one of the most pivotal periods and locations in the history of Western civilization: fifteenth-century, Renaissance Italy. Although hundreds, if not thousands, of studies have been devoted to this topic, there is little scholarship on the pedagogical value of its screened reinterpretations. The most prominent written scholarship on the Italian Renaissance includes Jacob Burckhardt's The Civilization of the Renaissance in Italy (1860), Power and Imagination: City-States in Renaissance Italy (1988) by Lauro Martines, Peter Burke's The Italian Renaissance, Culture and Society (2014), and The Italian Renaissance (2014) by Virginia Cox ${ }^{6}$. Burckhardt's authoritative study offers a brilliant

\footnotetext{
${ }^{5}$ For further info: http://www.pbs.org/about/blogs/news/national-ratings-cement-downton-abbey-season-3on-masterpiece-classic-as-highest-rated-drama-in-pbs-history/

${ }^{6}$ See also John Aldington Symons. Renaissance in Italy, 7 vol. (1875-86), Gene Bruckner, Renaissance Italy (University of California Press, 1983), M.J. Gill. The Italian Renaissance: The Origins of Intellectual and Artistic Change Before the Reformation (Routledge, New York and London, 1990), Stark, Rodney, The Victory of Reason: How Christianity Led to Freedom, Capitalism, and Western Success, (New York, Random House, 2005), Charles G. Nauert. Humanism and the Culture of Renaissance Europe (New Approaches to European History)Updated Edition (Cambridge University Press: London, 2006), Guido Ruggiero. The Renaissance in Italy: A Social and Cultural History of the Rinascimento (Cambridge University Press, 2015).
} 
panorama of Italian Renaissance life, explaining how and why the period constituted a cultural revolution. He opens his study by describing the Renaissance as part of a 'grand narrative' of the rise of modern Western civilization, "a triumphalist and elitist story that implicitly denigrated the achievements of other social groups and other cultures" (BURKE, 2014, p. 4). He chronicles the transition from the medieval concept of society-as a conglomeration of classes and communities-to the Renaissance focus on individual spirit and creativity. Burckhardt's comprehensive view of art, government, and aspects of daily life redefined both the Western world's understanding of the Italian Renaissance and future studies in cultural history. Burckhardt viewed the Renaissance as a modern culture created by a modern society. However, new perspectives have made Burckhardt's view seem quite archaic. Burke (2014) claims that this shift in attitude is due in part "to scholarly research on continuities between the Renaissance and the Middle Ages, but even more to changes in conceptions of the 'modern"' (p. 1). He furthers his stance by making an appeal to study the Italian Renaissance from a new perspective, by which he implies that it "should be reframed - in other words, detached from the idea of modernity - and studied in a 'decentered' fashion” (p. 3). In this article, I take up Burke's challenge by examining the decentered ways in which the Italian Renaissance is constructed in the Medici series, and by exploring its pedagogical value.

The series covers three seasons, which follow the ebb and flow of the Medici family history, while exploring the political and artistic landscape of Renaissance Italy. The first season, titled Medici: Masters of Florence (2016), takes place in 1429, when Giovanni Bicci de' Medici, head of the family, died. His son Cosimo de' Medici succeeds him as head of the family bank (at the time the richest of Europe), and fights to preserve his power in Florence. The second season, titled Medici: The Magnificent (2018), takes place 20 years later and tells the story of Cosimo's grandson Lorenzo de' Medici (known as the Magnificent). The third season, The Magnificent: The Beauty and The Power (2019), concludes the story of Lorenzo, who "has become a man who will have to fight against his demons and defend Florence from new internal and external threats" (Luca Barnabei in VIVARELLI, 2018). Despite being criticized for some historical inaccuracies, the series reached between four and eight million viewers on original airings. According to Italian ratings compiler Auditel, the first 
episode attracted a record 8.04 million viewers (LOPES, 2016)7. Since inaccuracies are rectifiable in classroom situations, I urge teachers to consider the overall pedagogical value of the series: a historically set fictional drama that allows viewers to experience affective engagement with the psychology of real-life characters, thus enabling a deeper level of learning.

\section{Jacopo Pazzi: Applying historical psychology}

In this article I will focus my attention on the pedagogical impact of the second season, which mainly addresses the rivalry between the young idealist, Lorenzo de' Medici, and the ruthless older banker, Jacopo Pazzi. In an online review of this season, Mellor flawlessly posits:

In the blue corner, young idealist Lorenzo de' Medici, a banker with a keen sense of social responsibility and one of history's most influential patrons of the arts (without him and his family, there wouldn't be Botticelli paintings hanging in the Uffizi today). In the red corner, Jacopo Pazzi, a ruthless and predatory money man with no sense of the value of art. It's youth vs age, revolution vs establishment, art vs empty materialism. (2019)

Students perceived that a number of Manichaean dichotomies, such as those listed above as well as those of the hero vs. the antihero, love vs. hate, and darkness vs. light, make up the driving forces of the entire narrative. On an ethical level, this is consistent with the educational "editorial line" of RAI and Lux Vide (BARRA and SCAGLIONI, 2015, p. 67). The series' poster visualizes these dichotomies, instantly setting the tone for the second season (Fig.1).

\footnotetext{
7 The series is broadcast in several countries; Netflix carries the show in the US, Canada, Argentina (on Fox Premium), the UK, Ireland, and India. SFR's premium SVOD service Zive airs it in France, and Sky 1 in Germany. In Australia, the series was broadcast by SBS; in Portugal, by RTP1. In Serbia the series was aired by RTS2.
} 


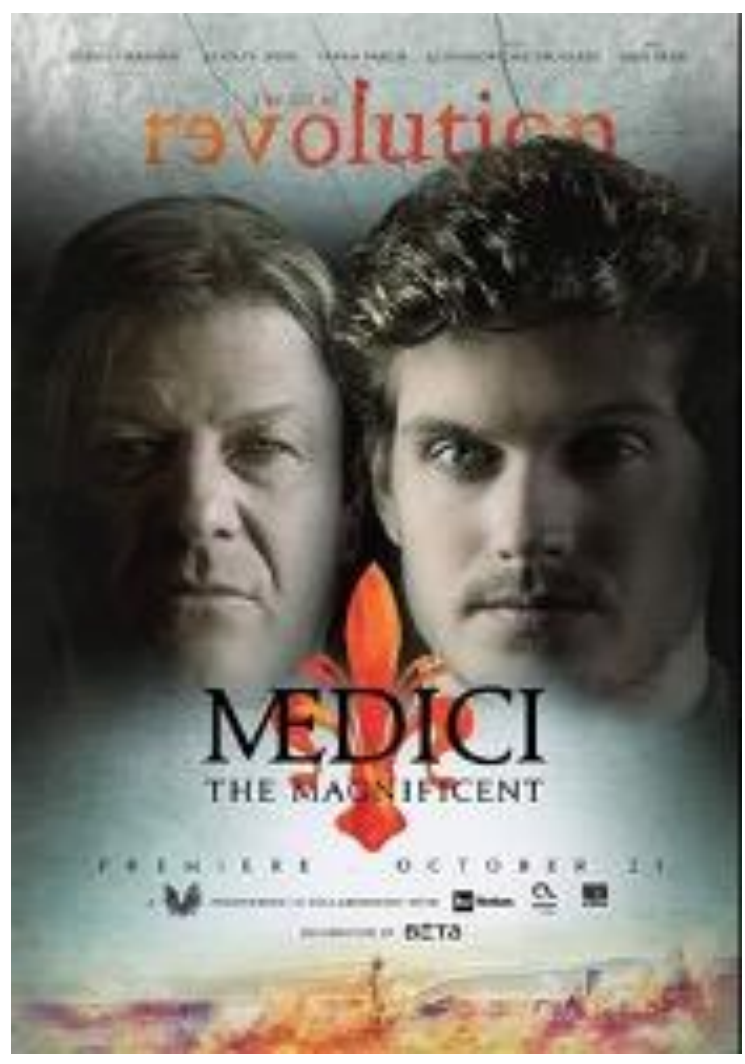

Fig.1 Medici: The Magnificent (2018): the poster.

Although completely unfamiliar with the historical timeline, students immediately identify the Italian Renaissance as a period of transitional social forces moving between two ideological and cultural, epistemic contexts: the medieval, aristocratic worldview (incarnated by Jacopo Pazzi) and the new mercantile ideology of the Renaissance (personified by Lorenzo de' Medici). Indeed, the Pazzi family represents medieval aristocracy, which is resistant to social and cultural change. Aristocrats are morbidly protective of their assets, cruel towards the poor, and afraid to lose their privileges by those who rise up the social ladder. In contrast, the Medici family represents the modern, rapidly advancing social class of merchants and bankers who are growing richer than the outmoded aristocracy, but who lack noble titles. Unlike the old nobility, the new social class is intellectually refined, and understands the importance of favoring the artistic growth of Florence by sponsoring artists, poets, and scholars. Students can relate to this conflict in a variety of contemporary ways. For instance, my ‘digital native’ students often express their frustrations with an older generation of backward, 'digital immigrants', as they effortlessly navigate their daily routine. 
The series allows students to visualize and actively comprehend these two perspectives, their distinct ethical beliefs, and their values. Historically, the Pazzi had a distinguished Florentine lineage, but in the fourteenth century they were forced to set aside their aristocratic rank in order to enter the banker's guild. Historical records prove that Jacopo's nephew, Francesco de' Pazzi, began to harbor a grudge against the Medici, as he resented "the airs put on by the Medici, as well as their power and money" (STRATHERN, 2017, p.161). Historical chronicles by Machiavelli and Poliziano indicate that Francesco was the mastermind behind the infamous Easter Day conspiracy in 1478, which led to the premature death of Lorenzo's beloved brother, Giuliano ${ }^{8}$. However, as an act of historical adaptation and "a process of creation" (HUNCHEON, 2012, p. 8), the TV series shifts the source of animosity to the older villain Jacopo; the show thus suggests that Jacopo manipulates Francesco, which leads to the Pazzi conspiracy and Giuliano's murder. By doing so, the writers magnify the wickedness of Jacopo and increase the chasm between the two sides. This historical discrepancy is in line with the series' Manichaean, ideological orientation; the elder characters usually symbolize evil and corruption, while the younger stand for goodness and integrity, albeit with a few exceptions. Most students did not align with Jacopo, because of his spiteful behavior and aggressive body language. They were put off by his verbal and nonverbal cues, which do not conform to commonly accepted moral judgment. Moreover, the mise en scène that accompanies Jacopo's character arc-composition, color, editing, music, costume, scenery-clearly underscores his sinister disposition. The first time Jacopo's character appears on screen, for example, he radiates evil and ominous power due mostly to low-angle, medium frames, dark lighting, and the music's rhythmic drum cadences (Fig.2).

\footnotetext{
${ }^{8}$ For further reference on the Pazzi Conspiracy, see: "Della congiura de' Pazzi dell'anno 1478. Comentario di Angelo Poliziano voltato dal latino in toscano da Alessandro De Mandato"; Stamperia del Vaglio; Napoli, 1849 ; Hibbert, Christopher. The House of Medici: Its Rise and Fall. Morrow, 1976; Rubinstein, Nicolai. The Government of Florence Under the Medici (1434 to 1494). 2nd ed., Clarendon Press, 1997; Strathern, Paul. The Medici: Godfathers of the Renaissance. Jonathan Cape, 2003; Martines, Lauro. April Blood: Florence and the Plot Against the Medici. Oxford University Press, 2003. Strathern, Paul. The Medici: Power, Money, and Ambition in the Italian Renaissance. First Pegasus books paperback edition., Pegasus Books, 2017.
} 


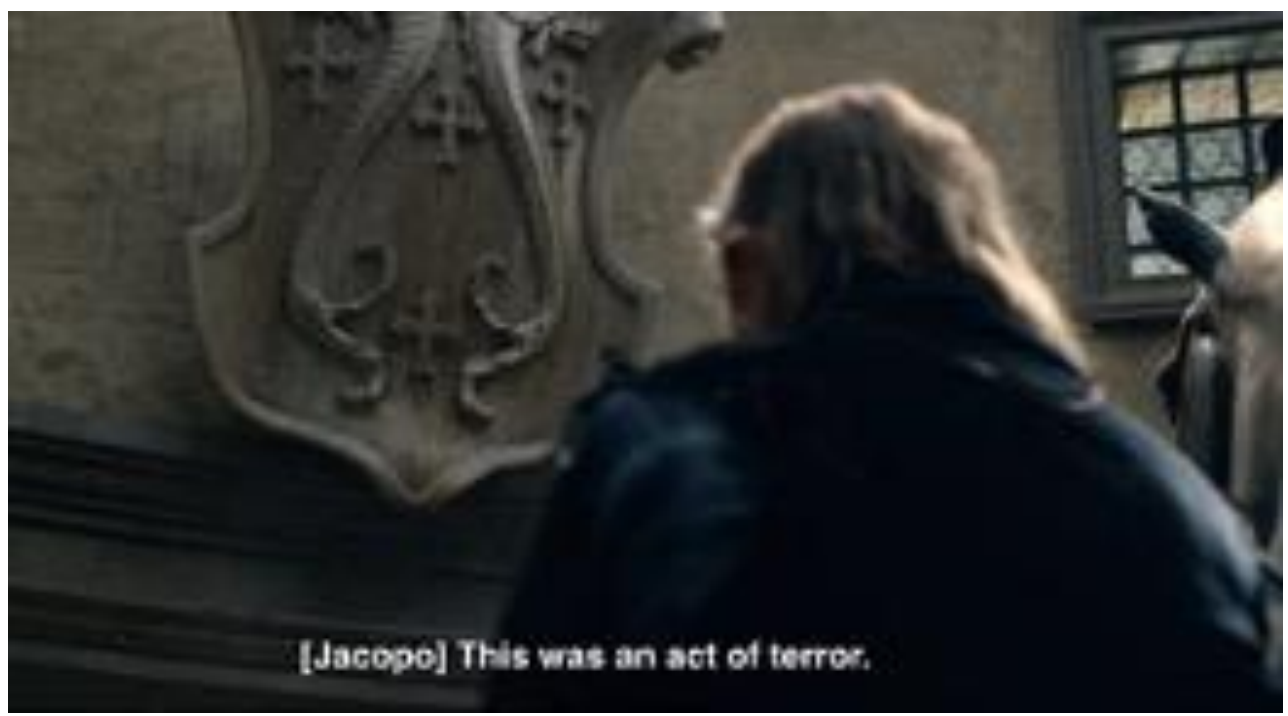

Fig.2 Medici: The Magnificent (2018): Jacopo Pazzi (Sean Bean) clothed in darkness (episode 1, season 2).

Jacopo's residence is filled with symbols that elicit fear and project power: statues of dark horses, window bars, golden coins, weapons, daggers, and swords. His clothing is always dark, and the tone of his voice is chilling and intimidating. The writers leave little room for ambiguous interpretation of the evil character, which allows students to focus on the circumstances that lead to Jacopo's problematic psychological state. As an online anonymous review of the series stated: "Bean truly brings the character of Jacopo to life and from the get-go, I utterly despised the character" (ANON, 2019). Thus, the writers steer us towards using the pedagogical technique of removing variables, so that we can focus on a common classroom activity: identifying the main characters' hero and antihero features. Classroom discussion questions may include: what makes it difficult to maintain allegiance to Jacopo? Can viewers identify any logical motivations for his behavior? Are his brutal actions completely irrational? Is he morally ambivalent?

However, despite the seemingly well-defined narrative, the Manichaean vision of the diegetic world of Medici slowly starts to weaken; this is where deeper and more complex learning begins. Viewers are soon introduced to intimate details that offer an insight into Jacopo's psyche. For instance, the loss of his wife and children during childbirth can serve as cues for students to examine this historical figure's vulnerabilities and 
traumas. His failed masculinity, in line with the series' melodramatic tendency, offers a humanizing and beguiling counterpart to his brutality. Although Jacopo never attains the status of "sympathetic perpetrator" (RENGA, 2019), a glimpse at his insecurities and vulnerabilities makes the character more recognizably human, thus increasing his empathetic appeal. Even though students are learning history, they are compelled to make analytical decisions: do they experience "sympathy for the devil"9, or do they reject compassion because Jacopo continually hurts heroes to whom viewers show allegiance, namely Lorenzo and Giuliano de' Medici?

In this way, students are not simply reading history, but they are engaging with its characters on a deeper level, prompted by writers who draw them in through creative license. At this point, students can be asked the following questions: if you sympathize with Jacopo's traumatic past experiences, does it make you re-evaluate your allegiance to the Medici family? Did Jacopo experience these traumas through cosmic karma, and do you thereby retain your allegiance to Lorenzo? Is your allegiance further complicated by the cosmetic details of the production, such as lighting, costumes, and sets? Are you disappointed by, and even mourn, Jacopo's death by hanging? In the end, his execution is part of history, but the possible shifts of allegiance - thanks to the series' serial deliveryresult in more meaningful pedagogical experiences for the students. The latter are not merely conforming to a history book's alleged objective perspective: they are given agency in contextualizing and revisiting characters and events. This type of learning likewise aligns with the RAl's didactic programming model ${ }^{10}$.

The portrayal of a psychologically unstable Jacopo reflects the melodramatic undertone of Medici, which is in line with Jason Mittell's definition of complex television as

\footnotetext{
${ }^{9}$ According to Carroll, the sympathy for the devil is the paradox whereby a viewer "can be sympathetic (care for or have a pro-attitude) toward a fictional character whose real-world counterpart she would totally abhor" (2004, p. 122).

${ }^{10}$ According to Renga, the deaths of male mafia perpetrators who are depicted in a sentimental light provoke mourning among the audience. Clearly, viewers tend to forgive their transgressions. In mafia films, "all of which fall under the rubric of male melodrama, male characters find absolution at the film's close." (Renga, 2019, I Kindle location 623). In the Medici series, Jacopo's sins are not condoned. The "redemptive formula" is not at work in Renaissance-based historical series, but only in narratives based upon actual, recent or ongoing, phenomena (Renga, 2019, location 623).
} 
"serial melodrama”"1. According to Mittell (2015), serial melodrama is a narrative mode "which unites various forms of serial television via a shared commitment to linking morality, emotional response, and narrative drive" and appeals to a variety of audiences (p. 244). In addition, the thesis that "melodrama presents characters who embody primary psychic roles organized in Manichaean conflicts between good and evil" (WILLIAMS, 1998, p. 77) corresponds with the series' pedagogical potential. Williams insightfully argues that "melodrama, most fundamentally, wants us to care for its protagonists" (p.177), and the screen time that an audience spends with the characters is intrinsic to melodrama, because it allows for the forming of powerful affective emotions in viewers.

"With serial melodrama, the more time we devote to getting to know sympathetic perpetrators, the more we feel connected to them" (RENGA, 2019, location 358); we can thus enter their psyche to better understand their dysfunctions. This melodramatic aspect, which is representative of "sustained storytelling time" (MITTELL, 2015, p. 244), enables the audience to actively learn the characters' inner turmoil and uncover-through historical psychology — new aspects of the past that may enrich the empirical knowledge acquired through written textbooks. Through Medici, today's students are exposed to historical facts by means of an entertaining serial modality they know very well. In other words, history is delivered in a more palatable manner for today's Generation Z learners.

\section{Lorenzo the Magnificent: Yet another complex allegiance}

So far, I have considered the psychological identikit of a villain that students may continue to re-examine throughout the series. In my discussion of the hero, Lorenzo de' Medici, and of his family, I will now borrow terminology of a form of historical learning, namely that of "remediation". ${ }^{12}$ According to official historiography, the Medici family

\footnotetext{
"Mittell defines "Complex Television" in terms of a narrative complexity that "redefines episodic forms under the influence of serial narration." It is a form of narration that "foregrounds ongoing stories across a range of genres" (Mittell, 2015, p. 18, original italics).

${ }^{12}$ In their seminal study Remediation: Understanding New Media (1999), David Jay Bolter and Richard Grusin introduced the concept of "remediation" in order to describe "the formal logic by which new media refashion prior media forms" (p. 273). What they observe is "the mediation of mediation". Not only in today's new media cultures, but at least since the Renaissance, media have continually been "commenting on, reproducing, and replacing each other, and this process is integral to media. Media need each other in order
} 
ruled Florence during most of the Renaissance period, and played an important part in the patronage of the arts and the city's political development ${ }^{13}$. At the onset, the Medici were wealthy wool merchants who became very powerful. Eventually, Giovanni Bicci de' Medici even became the banker of the Papal Court in 1397; his son, Cosimo, inherited an immense fortune. By 1434, Cosimo had consolidated power for himself and his family in Florence, all the while maintaining the appearance of democratic government.

Cosimo clung to his position as a private citizen, but it was clear to all that he ruled the city from behind the scenes. In spite of this, and the fact that Cosimo maintained his power through the actions of a manipulative schemer, other aspects of his life were nothing but admirable. He generously supported the arts, commissioned great cathedrals, and hired the best artists of the age to decorate them. He demonstrated vast support for education; for example, he established the Platonic Academy for the study of ancient works. It is estimated that, until his death in 1464, Cosimo spent approximately 600,000 gold florins to support architecture, scholarly learning, and other arts. This is an extraordinary amount if one considers that the unprecedented fortune his father left Cosimo totaled only 180,000 florins.

After Cosimo's death in 1464, his son Piero ruled for five years, and was then succeeded by Cosimo's grandson, Lorenzo de’ Medici, known as 'Il Magnifico'. Lorenzo "was born to rule" (UNGER, 2008, p. 24), lived more elegantly than Cosimo had, and enjoyed his position of power immensely. He was the first in his family to be born 'to the purple', and this awareness of an almost imperial destiny "shaped his sense of himself and the attitudes of those around him" (UNGER, 2008, p. 24). Under his control, Florentine economy expanded significantly, and the lower class enjoyed a greater level of comfort and protection than it had before. During the period of Lorenzo's rule, from 1469 to 1492, Florence became the most important city-state in Italy, and perhaps the most beautiful city

to function as media at all" (p. 55). According to Astrid Erll and Ann Rigney, "[t]he concept of remediation is highly pertinent to cultural memory studies. Just as there is no cultural memory prior to mediation there is no mediation without remediation: all representations of the past draw on available media technologies, on existent media products, on patterns of representation and medial aesthetics" (2009, p. 4).

${ }^{13}$ For further reference on the Medici, see: Strathern, P. (2017). The Medici: Power, money, and ambition in the Italian Renaissance (First Pegasus books paperback edition.). New York, NY: Pegasus Books. 
in all of Europe. Historian Francesco Guicciardini aptly characterized the contradictions of Lorenzo's rule as “that of a benevolent tyrant in a constitutional republic" (STRATHERN, 2017, p. 146).

Throughout the second season of Medici, Lorenzo is portrayed as both a kindhearted and charismatic young man. He enjoys the company of his family and friends, has a keen sense of art and poetry, is proficient in jousting and swordsmanship, and tries to maintain peaceful relationships with his enemies. Lorenzo's affable and resilient disposition is clear from the beginning, when he proves his swordsmanship skills by saving his father's life during a failed coup to overthrow the Medici and break their influence on the Florentine government, called Signoria ${ }^{14}$. However, the apex of masculine glory is soon followed by feelings of crisis and remorse. Indeed, in order to save his father, Lorenzo is forced to kill a conspirator. Talking to his mother, he confesses the deed with eyes swollen from tears: "I killed a man today. I watched the life drain from his eyes [...] everything he will ever be is gone from this world, forever" (Fig.3).

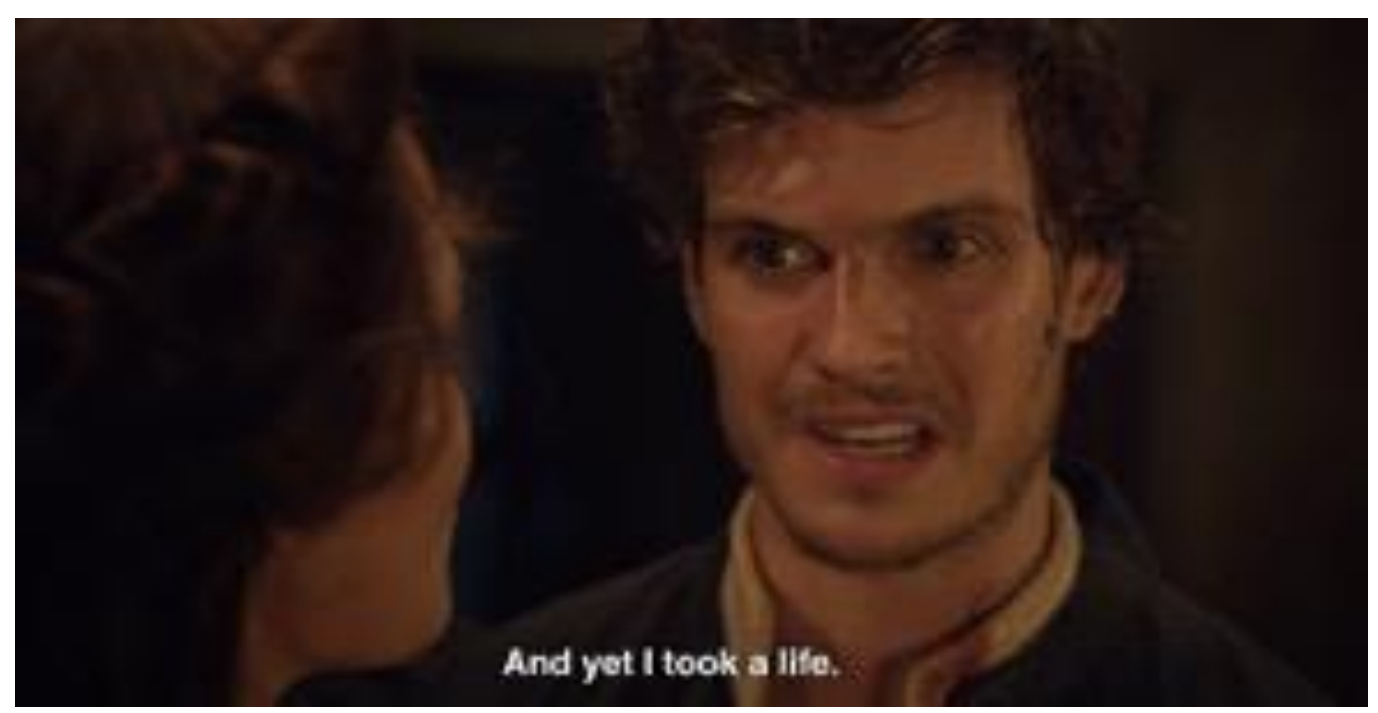

Fig.3 Medici: The Magnificent (2018): Lorenzo's remorse after killing a man (episode 1, season 2).

\footnotetext{
${ }^{14}$ The Signoria was the government of Medieval and Renaissance Florence. Its nine members, the Priori, were chosen from the ranks of the city's guilds: six of them from the major guilds, two from the minor ones. The ninth became the Gonfaloniere of Justice.
} 
By highlighting Lorenzo's sympathetic nature, this scene increases the character's empathetic appeal and intensifies audience alignment with and allegiance to Lorenzo. Alignment is achieved, as Smith explains, by "two interlocking functions, spatio-temporal attachment and subjective access" (SMITH, 1995, p. 83). Spatio-temporal attachment identifies the viewer's connection to a character based on overall screen time, while subjective access indicates a kind of psychological knowledge that is granted to the audience through the film's narrative. Finally, allegiance "pertains to the moral evaluation of characters by the spectator" (SMITH, 1995, p. 84). This consists of viewing and evaluating the moral actions of a character based on the knowledge of their cognitive state. Thus, students approaching the series might experience an affective engagement, or 'empathy,' with Lorenzo. We can apply the same questions to Lorenzo that we did to Jacopo: is he an unquestionably positive hero and someone we can trust? Do we mentally justify his violent act?

Perhaps the audience's allegiance to Lorenzo is secured during the first episode of this second season. Lorenzo is portrayed as the man destined to lead the family to greatness. During a flashback, Contessina de' Bardi illustrates the meaning of Benozzo Gozzoli's fresco, Procession of the Magi, to her young grandchild Lorenzo (Fig.3).

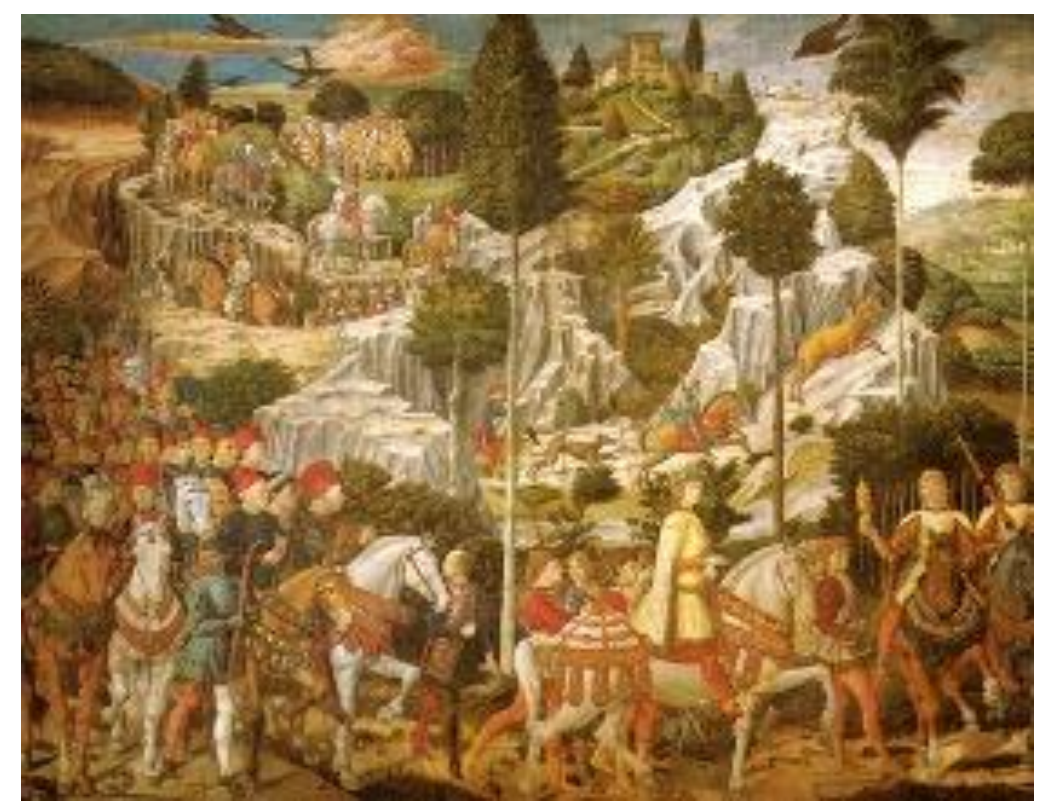

Fig.3: Benozzo Gozzoli, Procession of the Magi (1459-1460). Detail of the right wall of the Medici Chapel, showing one of the Magi in arrival. Palazzo Medici-Riccardi, Florence $\odot 2016$. 
Lorenzo's grandmother reveals that, by being compared to a Magi, he is destined by God to lead the Medici family to greatness. This pivotal scene, then, offers students a chance to combine knowledge about art, religion, and politics, as it allows them to consider the utilitarian function of Renaissance art and its interaction with religion and political power. During the Italian Renaissance, powerful families, rulers, popes, princes, and kings became patrons of the arts, alias mecenati. They commissioned art works, frescos, statues, buildings, and churches, in an effort to project their power onto society and consequently earn respect, honor, and glory.

The Medici family was one of the most prominent patrons of the arts during the Renaissance, and fostered art "to broadcast to the various groups that supported them in Florence, and to foreign visitors and dignitaries as well, their quiet (and at time not-soquiet) glory, religious commitment, and power" (RUGGIERO, 2015, p. 339). Gozzoli's fresco, in particular, had a deep political significance, as it was located in a small chapel in the Medici Palace, where the family received visitors from outside Florence. By connecting this family to the biblical Magi, the Medici conveyed the impression that they were blessed by God in their rule of Florence under the guidance of Lorenzo. As Ruggiero (2015) posits, "the Magi connection was an easily recognized and powerful one; and Gozzoli represents it in a way that stresses both the family and the individuals who made it great" (p. 340). Thus, students learn a pivotal concept of the Italian Renaissance: the centrality of artistic patronage. In his Ricordi, Lorenzo de' Medici wrote the following:

I find that from 1434 through 1471 my family has expended enormous amounts of money ... the sum is an incredible 663,775 florins spent on charity, buildings and taxes, as well as other expenses. I do not, however, regret this, although some would say it would have been better to keep a part of that aside in one's purse, I believe it casts a brilliant light on our state, and it seems to me well spent, and for that I am very pleased. (1919, p. 98)

The lavish spending of the Medici family —and of Florentine elites in general —was fundamental to the explosion of artistic creativity during the latter half of the fifteenth century. In this regard, Kaborycha (2011) states that spending, "shorn of its overtones of 
sinfulness and excess, [... ] was now in fashion" (p.174). The series elucidates this point by highlighting not only the Medici's patronage, but also the extent to which other Florentine families spent money on portraits, buildings, and works of art.

Through the figure of Lorenzo, and in the three seasons of Medici in general, students steadily learn about the history, arts, politics, and important figures of the fifteenth-century Italian Renaissance. Once again, though, by the end of the second season, it is also possible for them to return to the practice of historical psychology, now through an examination of the established Lorenzo character and his family. Students can thus consider the spirit of the Medici, and their true intentions: was the family stimulated to act as patrons by their love of the arts, or was it primarily a 'marketing' campaign? Was the family devout in their faith, or did they leverage the religious environment to expand the breadth of their power? Are there any contemporary figures that might be considered in an analogous way, whose actions might be clouded, for example, by a complicated assortment of financial, national, and religious motivations?

The series shows how famous Renaissance artists and poets (such as Sandro Botticelli and Angelo Poliziano) interacted with the Medici and are treated as family members. Thus, Lorenzo is associated with "the spectrum of positive affect" (LOMAS, 2017, p, 1): magnificence, intelligence, virtue, beauty, and glory. This portrayal justifies the directors' choice to cast the physically attractive Daniel Sharman ${ }^{15}$ for the role of Lorenzo de' Medici (Fig.5), who in reality was notorious for his unattractiveness (fig.6):

There is no doubt that from the outset Lorenzo de' Medici was impressive, though curiously we know from his many portraits that his physical appearance was distinctly unimpressive. In this, he was very much a Medici. His sallow features were undeniably ugly by lank centre-parted hair that fell to his shoulders; below his beetled brow his eyes were heavylidded, like his father's. He had an over-emphatic chin with a protruding lip, while his nose was broad and squashed [...] His movements were clumsy, his figure tall and powerfully built, but ungainly; only his hands were long and delicate. (STRATHERN, 2017, pp. 149-150)

\footnotetext{
${ }^{15}$ Sharman is known for his roles as Isaac Lahey in the TV series Teen Wolf (2012-2014), Kaleb Westphall/Kol Mikaelson in The Originals (2014-2015), and Troy Otto in Fear the Walking Dead (2017).
} 


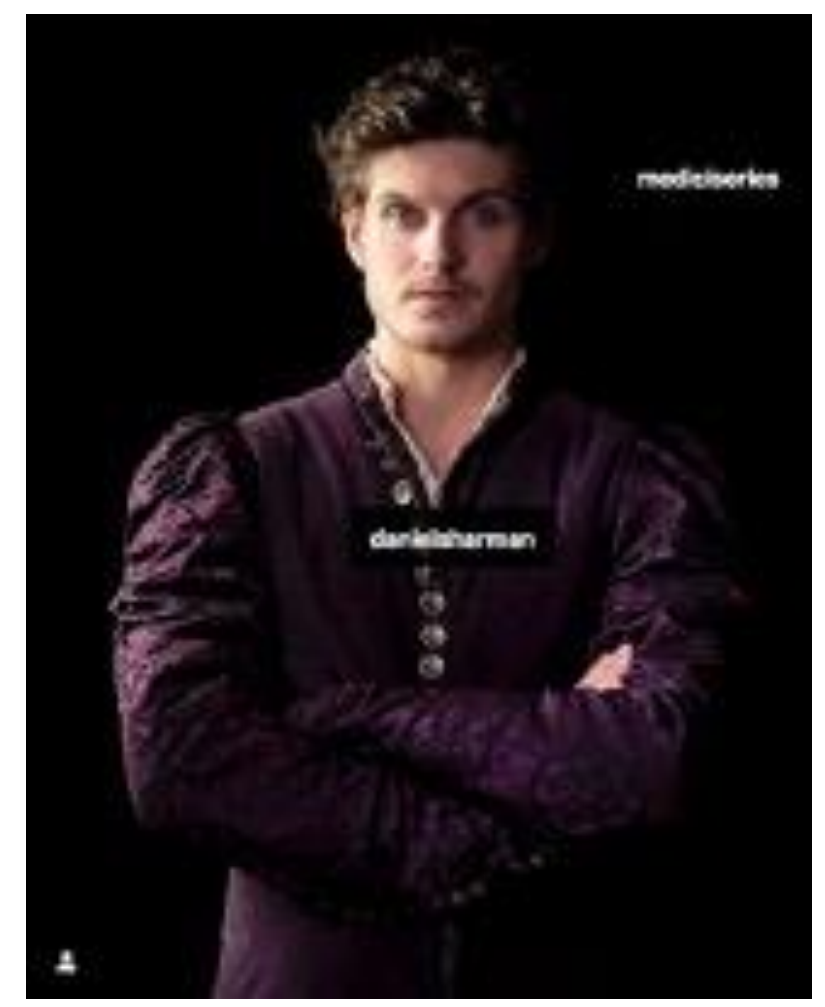

Fig.5: sharmanslays. New promotional photo of Daniel as Lorenzo De Medici.Via @mediciseries on Twitter).

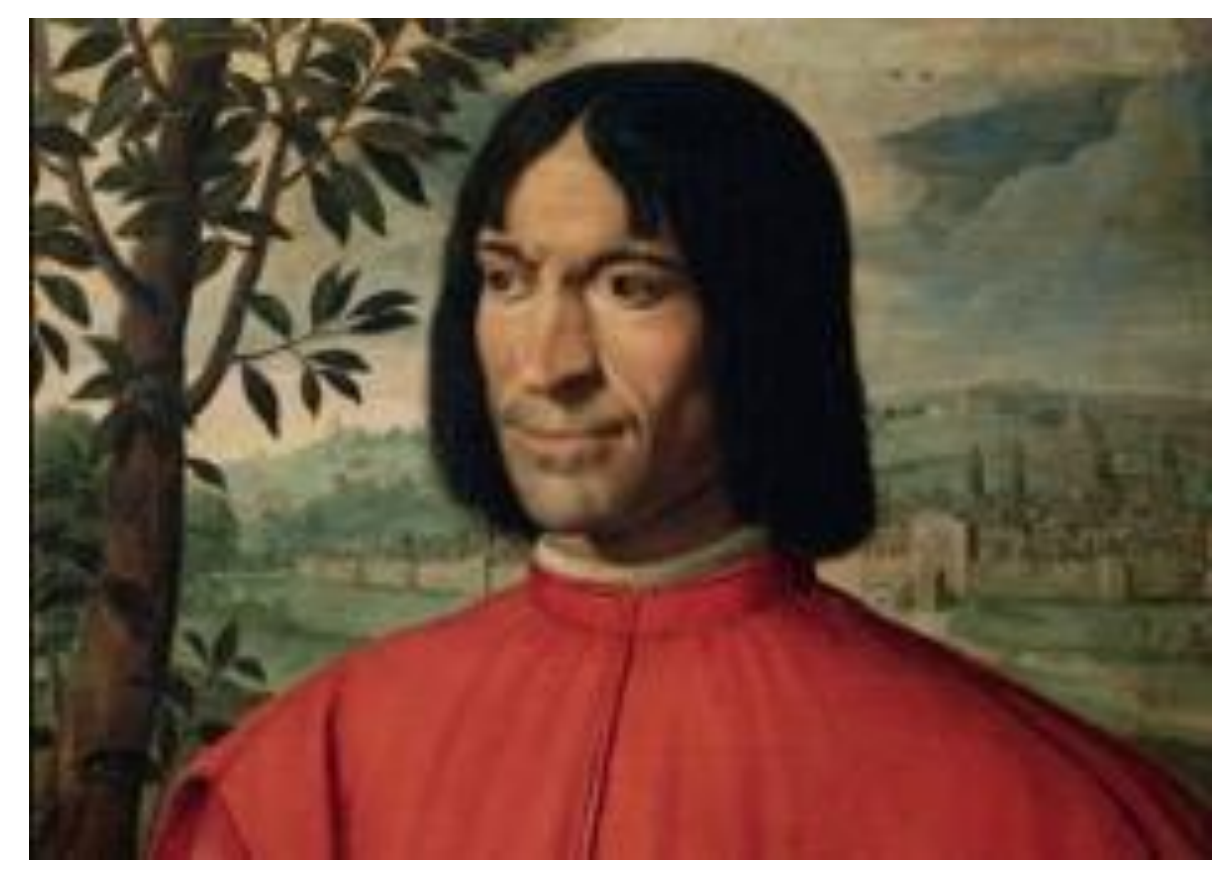

Fig.6: Luigi Fiammingo, Portrait of Lorenzo de' Medici, called The Magnificent (c. 1550). Detail. Palazzo Pitti, Florence @Hans Ollermann 2018. 
The televised loose adaptation of a handsome Lorenzo has a twofold effect: it meets the aesthetic requirements of the audience's visual pleasure, and it reinforces the spectrum of positivity anchored in this character ${ }^{16}$.

However, Lorenzo's initial 'hero' status soon begins to fade; his devotion to his family and moral integrity are tainted by his lustful affair with Lucrezia Donati, and his political stature is compromised when his alum claims in Volterra lead to a violent massacre ${ }^{17}$. Although these scenes do not completely demythologize Lorenzo, they gradually erode the aura of excellence that centuries of historiography have built around his reputation. In this way, the series introduces the viewers to alternative historical interpretations, and invites students to examine the Italian Renaissance with fresh eyes. Indeed, this new perspective allows them to consider historical aspects they may not have previously known or comprehended.

They are thus in a position to confront their historical knowledge with the new cultural and historical claims presented on the screen. Moreover, they are challenged to reflect on Lorenzo's psychological state: is he a good person, forced to commit evil acts in order to retain power (following the Machiavellian logic that "the ends justify the means")? Or is he masking his maliciousness with a facade of honesty? By having students speculate on the hypothetical psychology of historical characters, learning history can turn into a pedagogically engaging exercise, even a performance. The resulting, novel appreciation moves beyond rote learning and allows participation in a vast forum of historical discussion and interpretation.

\footnotetext{
${ }^{16}$ In reference to the way audiences watch and engage with television as a source of visual pleasure tied to the erotic, see Wheatley, Helen. "Visual Pleasure and Narrative Television" Feminist Media Studies, vol. 15, no. 5, Taylor \& Francis Ltd., Sept. 2015.

${ }^{17}$ The mineral alum was a key commodity in the glassmaking, tanning and textile industries. During that time, alum was available from only a few sources under the control of the Ottomans and monopolized by Genoa before the discovery of alum sources in Italy near Volterra. Initially, the people of Volterra turned to Florence and the Medici to get backing to exploit this important natural resource. When they realized the value of the alum mine, the people of Volterra wanted its revenues for their municipal funds rather than having it enter the pockets of their Florentine backers. Thus, began an insurrection against the Florentine alum monopoly. Lorenzo sent mercenaries to suppress the revolt by force, and the mercenaries ultimately sacked the city. Lorenzo hurried to Volterra to make amends, but the incident would remain a dark stain on his record.
} 


\section{Contemporary modes of engagement with Medici}

As an example of transmedia storytelling ${ }^{18}$, the series Medici: The Magnificent offers a variety of paratexts that aim at understanding, discussing, and expanding its meaning. Students may decide to refer to these online discussions and exchanges in order to share, confront, and reorient their interpretation. Thirteen Facebook profiles (with an approximate total of 315,423 followers), three Twitter tags (with an approximate of 7,838 tweets), 14 Instagram pages (with an approximate of 295,660 followers), several IMDb reviews (i.e., 110 user reviews and 11 external critic reviews), and more than 300 YouTube videos (containing interviews, reviews, and extras) offer appealing platforms for students and viewers to discuss historical topics, negotiate knowledge, and arrive at informed interpretations.

The series and its historical content were frequently praised: "I think this is a great series for entertainment and history.... It did inspire me to do more research on the Medici family. I discovered the series isn't entirely historically accurate but then we are talking about events that happened or not over 500 years ago..." (IMDb by \#adencrane, December 11, 2016); "Love that a series would tackle the era and the real pressures that such a significant person faced. Medici was inspiring, educational and looked beautiful" (IMDb by \#jilena0081, January 1, 2017); "If this is your first experience with the subject, then by all means enjoy this melodramatic version. And if the beauty of the Medici Renaissance enthralls you, then follow up with the PBS series - Medici: Godfathers of the Renaissance. And some day spend a week or a month in Florence - six centuries and still one of the most refulgent blossoms on the planet" (IMBd by \#richardolivermcrae, December 13, 2016).

These reviews reinforce the notion that the Medici series possesses pedagogical value. Students and viewers may uncover important historical concepts about the Italian Renaissance, or expand on ideas they have encountered in school, history books, or films. Although Medici is indeed a highly dramatized version of history, it may serve as a prompt

\footnotetext{
${ }^{18}$ According to Jenkins, "[ $\left.\mathrm{t}\right] \mathrm{ransmedia}$ storytelling represents a process where integral elements of a fiction get dispersed systematically across multiple delivery channels for the purpose of creating a unified and coordinated entertainment experience. Ideally, each medium makes it own unique contribution to the unfolding of the story" (blog, August 1, 2011).
} 
for viewers to investigate other-perhaps more 'legitimately' historical—series, such as the abovementioned PBS docuseries Medici: Godfathers of the Renaissance (2004). Overall, we should embrace this important moment in television history, as the quantity and quality of new historical TV series increase each year. We should be on the lookout for programs like Medici, as they serve as a pedagogical 'springboard' for historical research.

\section{Final thoughts}

Medici: The Magnificent offers just one example of how a historical TV series can be used to teach the past in language and culture classes. Instructors can work around historical inaccuracies and leverage its serial format, so as to entice binge-sensitive Generation Z students to connect with history through their preferred modality. Indeed, the series' audiovisual technology enables students to engage with history in a more appealing way, and through a highly flexible and portable streaming delivery to their many devices. The show offers Renaissance history through popular media and activates the students' imagination, allowing them to reconstruct plotlines and motivations behind significant decisions of historical figures. The past is, then, no longer something contemporary students read about in textbooks or archives but becomes "a parallel world which is un-real, hyper-real, and virtual, all at the same time" (ELSAESSER, 1999, p.1).

This parallel world may also serve as a venue for emotional participation and historical psychology, as audio and visual cues enable bountiful opportunities for students to delve into the surface of events and dates and enter into the minds of history's more significant characters. My approach to Medici draws on my own implementing these theoretical frameworks, and the TV show, in my classes on the Renaissance; students have responded very positively, primarily because they felt they personally experienced thoughts and fears of characters, which allowed them to better understand complex situations. Although I am conscious that my approach to teaching history and cultural studies through audiovisual material may seem simplistic to those who prefer more traditional pedagogical approaches, my article argues that, moving forward, it may prove 
to become a highly relevant tool for enabling students to engage more profoundly with the past.

\section{References}

ABRUZZESE, Alberto. Lessico della comunicazione. Roma: Meltemi, 2004.

ANON, Review: Medici The Magnificent, The Borgia Bull, 2 Feb 2019, https://theborgiabull.com/2019/02/02/review-medici-the-magnificent/ Accessed on 20 December 2019.

BARRA, Luca; SCAGLIONI, Massimo. Saints, Cops and Camorristi. Editorial Policies and Production Models of Italian TV Fiction. Series. International Journal of Tv Serial Narratives, vol. 1, no. 1, University of Bologna, May 2015.

BOLTER, J. David, and GRUSIN, Richard. Remediation: Understanding New Media. MIT Press, 1999.

BURCKHARDT, Jacob. The Civilization of the Renaissance in Italy. Harper, 1958.

BURGOYNE, Robert. The Hollywood Historical Film. Malden: Wiley-Blackwell, 2008.

BURKE, Peter. The Italian Renaissance: Culture and Society in Italy. Polity, 1988.

COX, Virginia. A Short History of the Italian Renaissance. I.B. Tauris, 2016.

CREEBER, Glen. Serial Television: Big Drama on the Small Screen. BFI Publishing, 2004.

DE GROOT, Jerome. Consuming History: Historians and Heritage in Contemporary Popular Culture. London: Routledge, 2009.

ELSAESSER, Thomas. 'One Train May Be Hiding Another': Private History, Memory, and National Identity. La Trobe University, April 16 1999. http://tlweb.latrobe.edu.au/ humanities/screeningthepast/reruns/rro499/terr6b.htm Accessed on December 26, 2019.

ERLL, Astrid, and RIGNEY, Ann. Mediation, Remediation, and the Dynamics of Cultural Memory. Walter de Gruyter, 2009.

GUICCIARDINI, Francesco. Elogio di Lorenzo de' Medici. In Scritti politici e ricordi, by Francesco Guicciardini. Edited by Roberto Palmarocchi. Bari, 1933, p. 223-228.

HUNCHEON, Linda. A Theory of Adaptation. 2nd ed., Routledge, 2012. 
JENKINS, Henry. Transmedia 202: Further reflections. Confessions of an Aca-Fan (blog), August 1 2011, http://henryjenkins.org/blog/2011/08/defining_transmedia_further_re.html Accessed on 20 December 2019.

JONES, Vicki; JO, Jun; MARTIN, Philippe. Future Schools and How Technology can be used to support Millennial and Generation-Z Students. School of Information and Communication Technology Griffith University, Gold Coast Campus, QLD Australia http://citeseerx.ist.psu.edu/viewdoc/download?doi=10.1.1.390.3578\&rep=rep1\&type=pdf Accessed on 20 December 2019.

JURDJEVIC, Mark. The Virtues and Vices of Medici Power in the Florentine Histories. A Great and Wretched City, Harvard University Press, 2014.

KABORYCHA, Lisa. A Short History of Renaissance Italy. Edition no. 1. Upper Saddle River, N.J: Prentice Hall, 2011.

LANDSBERG, Alison. Prosthetic Memory: The Transformation of American

Remembrance in the Age of Mass Culture. New York: Columbia University Press, 2004.

LANDSBERG, Alison. Engaging the Past: Mass Culture and the Production of Historical Knowledge. Columbia University Press, 2015.

LOMAS, Tim. The spectrum of positive affect: A cross-cultural lexical analysis. International Journal of Wellbeing. 2017. 7 (3), pp. 1-18.

LOPES, Benjamin, Les Médicis, Maîtres de Florence: carton d'audience pour la série de SFR Play. Toutelatele. 26 Oct 2016. Retrieved from: http://www.toutelatele.com/lesmedicis-maitres-de-florence-carton-d-audience-pour-la-serie-de-sfr-play-85995 Accessed on December 182019.

MARKOVA, Is; BERRIOS, Ge. The Meaning of Insight in Clinical-Psychiatry. British Journal of Psychiatry, vol. 160, Cambridge University Press, June 1992, pp. 850-60.

MARTINES, Lauro. Power and Imagination: City-States in Renaissance Italy. 1st ed., Knopf, 1979.

MEDICl, Lorenzo. I ricordi. Lives of the Early Medici as Told in Their Correspondence. Ed. and trans. Janet Ross. London: Chatto \& Windus, 1910. 150-156.

MELLOR, Luisa. Medici season 2: Frank Spotnitz interview "the real history is too graphic even for television to show". Den on Geek, 12 Jan 2019. Retrieved from:

https://www.denofgeek.com/uk/tv/netflix/62930/medici-season-2-frank-spotnitzinterview-the-real-history-is-too-graphic-even-for-television-to-show Accessed on December 182019. 
MITTELL, Jason. 2015. Complex TV: The Poetics of Contemporary Television Storytelling . New York and London: New York University Press, 2015.

NELSON, Robin. TV Drama in Transition: Forms, Values, and Cultural Change. London: Macmillan, 1997.

PEREBOOM, Marteen. History and Film: Moving Pictures and the Study of the Past. Routledge, 2010.

RENGA, Dana. Watching Sympathetic Perpetrators on Italian Television. Springer International Publishing. Kindle Edition, 2019.

ROSENSTONE, Robert A. Visions of the Past: The Challenge of Film to Our Idea of History. Harvard University Press, 1995.

RUBINSTEIN, Nicolai. The Government of Florence under the Medici (1434-1494). New York: Oxford University Press; 1997; 2nd ed.

RUGGIERO, Guido. The Renaissance in Italy: A Social and Cultural History of the Rinascimento. Cambridge University Press, 2015.

SCHNEIDER, Rebecca. Performing Remains: Art and War in Times of Theatrical Reenactment. Florence: Routledge, 2011.

SMITH, Murray. Engaging Characters: Fiction, Emotion, and the Cinema. Oxford: Clarendon Press, 1995.

STRATHERN, Paul. The Medici: Power, Money, and Ambition in the Italian Renaissance. First Pegasus books paperback edition, Pegasus Books, 2017.

TEAGUE, Ellen. Review - Medici: the Magnificent. Independent Catholic News, Aug 14t 2019. Retrieved from: https://www.indcatholicnews.com/news/37690 Accessed on 29 December 2019.

THANOULI, Eleftheria. History and Film: A Tale of Two Disciplines. Bloomsbury Academic, 2019.

UNGER, Miles. Magnifico: The Brilliant Life and Violent Times of Lorenzo De' Medici. 1st Simon \& Schuster hardcover ed., Simon \& Schuster, 2008.

VIVARELLI, Nick. Christian Duguay, Francesco Montanari Board 'Medici' Season 3. Variety, 28 Aug. 2018. Retrieved from: https://variety.com/2018/tv/news/medici-season-threechristian-duguay-francesco-montanari-1202918618/ Accessed on 18 December 2019. 
WAGNER, Curt. Richard Madden, Italy \& the 'Medici'. November 17, 2015

https://tvshowpatrol.com/news/richard-madden-italy-the-medici/ Accessed on 18 December 2019.

WHEATLEY, Helen. Visual Pleasure and Narrative Television. Feminist Media Studies, vol. 15, no. 5, Taylor \& Francis Ltd., Sept. 2015, http://search.proquest.com/docview/1726805285/. Accessed on 18 December 2019.

WHITE, Hayden. Historiography and Historiophoty. The American Historical Review, vol. 93, no. 5, 1988, pp. 1193-1199.

WILLIAMS, Linda. Melodrama Revised. in Refiguring American Film Genres: Theory and History, edited by Nick Brown, 1998, pp.42-88. Berkeley and Los Angeles: University of California Press.

WINEBURG, Samuel. Historical Thinking and Other Unnatural Acts: Charting the Future of Teaching the Past. Temple University Press, 2001. 